\title{
Material Evaluation to Prevent Nozzle Clogging during Continuous Casting of Al Killed Steels
}

\author{
Y. VERMEULEN, B. COLETTI, B. BLANPAIN, P. WOLLANTS and J. VLEUGELS \\ Dept. Metallurgy and Materials Engineering, K. U. Leuven, Kasteelpark Arenberg 44, B-3001 Leuven, Belgium. \\ E-mail: Bart.Blanpain@mtm.kuleuven.ac.be
}

(Received on May 10, 2002; accepted in final form on July 18, 2002)

\begin{abstract}
$\mathrm{Al}_{2} \mathrm{O}_{3}$-carbon composite submerged entry nozzles (SEN) are used for continuous casting of steels. Although this material has excellent mechanical and thermal properties, it frequently leads to clogging. The purpose of our research is to find a suitable refractory material that can be used to coat SENs. This paper reports on the chemical compatibility of a number of potential refractory materials: $\mathrm{Al}_{2} \mathrm{O}_{3}, \mathrm{ZrO}_{2}, \mathrm{Al}_{2} \mathrm{O}_{3}-$ carbon, $\mathrm{SiO}_{2}$ and $\mathrm{MgO}$ with liquid steel, an amount of simulated inclusions and synthetic slag. For this purpose, an experimental laboratory procedure was optimised to simulate the nozzle behaviour during continuous casting. $\mathrm{Al}_{2} \mathrm{O}_{3}$ was found to give satisfactory results, and therefore a $\mathrm{Al}_{2} \mathrm{O}_{3}$ plasma coated $\mathrm{Al}_{2} \mathrm{O}_{3}-$ carbon material was also tested in the laboratory with good results.
\end{abstract}

KEY WORDS: continuous casting; aluminium killed low carbon steel; clogging; nozzle; refractory materials.

\section{Introduction}

The continuous casting process accounts for $90 \%$ of the world's steel output and is considered to be a mature technology. ${ }^{1)}$ The submerged entry nozzle (SEN) plays a vital role in ensuring stable casting operations and slab quality. It is used to prevent oxygen and nitrogen pick-up and to achieve a desired steel flow in the mould. Clogging of SENs, i.e. a substantial reduction of the inner section of the nozzle due to the deposition of material consisting mainly of steel and inclusions on its inner wall, however remains a problem. Clogging eventually leads to a disruption of normal casting operations.

The refractory material of the SEN should have adequate chemical inertness and mechanical properties such as high temperature mechanical strength and thermal shock resistance. ${ }^{2)}$ Currently, mainly $\mathrm{Al}_{2} \mathrm{O}_{3}$-carbon is used as the base material for the production of SENs, while fused silica and $\mathrm{ZrO}_{2}$-carbon occupy lower percentages of the SEN market.

Extensive scientific research has been carried out to investigate the mechanism of clogging (e.g. Refs. 3), 4)), to determine the interactions between the liquid steel flow and the refractory material of the SEN (e.g. Refs. 5), 6)) and to study the steel flow pattern in the nozzle (e.g. Refs. 7), 8)). A first reaction layer forms due to an increased oxygen activity near the refractory wall, causing the oxidation of $\underline{\mathrm{Al}}_{\mathrm{Fe}}$ to $\mathrm{Al}_{2} \mathrm{O}_{3}(\mathrm{~s})$. The increased oxygen activity can be caused by air leakage at the exchange mechanism, by air diffusion through the refractory material or by redox reactions in the refractory material. ${ }^{4}$ This latter source originates from the reduction of $\mathrm{SiO}_{2}, \mathrm{Na}_{2} \mathrm{O}$ and $\mathrm{K}_{2} \mathrm{O}$ by the carbon in the refractory, leading to the formation of $\mathrm{SiO}, \mathrm{Na}, \mathrm{K}$ and $\mathrm{CO}$ gas. When $\mathrm{CO}$ and $\mathrm{SiO}$ gas reach the liquid steel, they will raise the oxygen activity near the refractory wall. This causes the oxidation of $\underline{\mathrm{Al}}_{\mathrm{Fe}}$, while $\mathrm{Si}$ and $\mathrm{C}$ will dissolve in the liquid steel. ${ }^{6}$ )

Once this first alumina layer has been formed, deposition and accumulation of inclusions from the molten steel onto the inner wall of the SEN will occur. ${ }^{5)}$ The first alumina layer is considered to serve as an ideal substrate for this deposition process, as a rough refractory surface presents more energetically favourable sites for the deposition of alumina particles. ${ }^{9}$ ) It is also reported that the deposited material consists mainly of $\mathrm{Al}_{2} \mathrm{O}_{3}$ and steel but may also contain smaller quantities of $\mathrm{SiO}_{2}$ and $\mathrm{CaO} .{ }^{4,10)}$ It is supposed that most of the inclusions are formed in the liquid steel. ${ }^{11)}$ Once these inclusions adhere to the refractory wall, sintering occurs.

A number of possible ways to prevent clogging have been proposed, such as adaptation of the geometry of the nozzle, ${ }^{11-13)} \mathrm{Ca}$ treatments, ${ }^{14,15)}$ or Ar injection. ${ }^{8)}$

In this study we report on laboratory experiments that simulate nozzle exposure and which allow to select a promising material to coat SENs. The present investigation focuses on the influence of the chemical composition of the refractory material on the chemical compatibility with liquid steel, inclusions and slag.

\section{Experimental Procedure and Materials}

The laboratory tests were performed in a resistance heated graphite furnace (W100/150-2200-50 LAX, KCE Sondermaschinen, Rödental, Germany). The samples were tested at $1550^{\circ} \mathrm{C}$, the average casting temperature, for $150 \mathrm{~min}$ in an inert Ar-gas (Ar gas: Air Liquide, N39, 10 ppm $\left.\mathrm{O}_{2}\right)$ atmosphere. After evacuation $\left(<10^{-1} \mathrm{~Pa}\right)$ the fur- 
nace was filled with Ar gas to $3 \times 10^{4} \mathrm{~Pa}$, which corresponded to $7.5 \times 10^{4} \mathrm{~Pa}$ at $1550^{\circ} \mathrm{C}$. The apparent deviation from the ideal gas law is due to the limited hot zone within the furnace. An oxidising atmosphere is to be avoided since it causes oxidation of the liquid steel and the formation of $\mathrm{CO}$ gas in the case of carbon containing refractories. The $P_{\mathrm{O}_{2}}$ pressure near the inner wall of the SEN, in industrial practice, stands at approximately $10^{-8} \mathrm{~Pa}^{4}$ ) Therefore, the above mentioned conditions were selected because dynamic vacuum conditions are more difficult to correlate with industrial practice, as this causes the reduction of some components and leads to the decarburisation of carbon containing samples, as was observed in preliminary experiments. Thermodynamic calculations using the Ar gas composition and assuming an excess of $\mathrm{C}^{16}$ indicate a $P_{\mathrm{O}_{2}}$ of approximately $4 \times 10^{-20} \mathrm{~Pa}$ during the laboratory experiment. This oxygen potential will in practise be increased due to a reduction of the refractory samples.

For compatibility testing in the solid state, samples of the refractory material were prepared with dimensions of approximately $20 \times 10 \times 5 \mathrm{~mm}$. For the experiments with liquid steel, smaller specimens (approximately $10 \times 10 \times 5 \mathrm{~mm}$ ) were used. The specimens were placed in a corundum crucible. Three different tests were performed.

\subsection{Interaction with Liquid Steel}

Approximately $5 \mathrm{~g}$ of a low carbon, Al-killed, degassed steel (supplied by SIDMAR Steel Plant) was employed to perform the experiments. The aim of these tests was to investigate the chemical stability of the refractory material in contact with liquid steel.

\subsection{Sintering Behaviour of Clogging Material on Re- fractory Material}

Powder, consisting of a mixture of alumina particles and steel, was collected from the outer layer of clogging material present on a used SEN. The SEN originated from a 2 strand slab caster using stopper rod flow control and through which 5 heats of approx. 292 ton per heat of an LCAK steel grade had flowed. The alumina is present as corundum particles of which the size ranges between 1 and $5 \mu \mathrm{m}$. Their shape indicates they were formed in the melt. The steel is present as droplets with a size ranging from 1 to $2 \mathrm{~mm}$. The overall chemical composition of the collected clogging material was determined by X-Ray Fluorescence Spectroscopy (XRF Philips, PW2400) and is given in Table 1. To this purpose the powder was first crushed using a Retch RM 100 of which $0.3 \mathrm{~g}$ was subsequently fused with $6 \mathrm{~g} \mathrm{Li}_{2} \mathrm{~B}_{4} \mathrm{O}_{7}, 3 \mathrm{~g}$ and 3 droplets of $\mathrm{LiBr}_{2}$ into a glass bead using a Pearl'X 3 (Philips). A quantitative routine was used with seven standards made of variable compositions of available standards: $\mathrm{BS} 100 \mathrm{~A}$ and $\mathrm{BS} 101 / 3$, of $\mathrm{Al}_{2} \mathrm{O}_{3}$ (ACROS; Art. 21570) and of $\mathrm{Fe}_{2} \mathrm{O}_{3}$ (MERCK; Art. 2924).

The purpose of these tests is to investigate the effect of the refractory material on the sintering behaviour of inclusions and to find out whether the inclusions sinter to the refractory material. To this purpose the refractory material is heated together with an amount of 'inclusions', collected from a used SEN.

\subsection{Interaction with Slag}

In these experiments a synthetic slag layer was placed on
Table 1. Chemical composition of inclusions collected from a used SEN, as determined by XRF.

\begin{tabular}{|l|l|}
\hline Compound & [mass\%] \\
\hline $\mathrm{Al}_{2} \mathrm{O}_{3}$ & 53.78 \\
\hline $\mathrm{Fe}$ & 43.95 \\
\hline $\mathrm{SiO}$ & 1.39 \\
\hline $\mathrm{CaO}$ & 0.53 \\
\hline $\mathrm{MgO}$ & 0.24 \\
\hline $\mathrm{TiO}_{2}$ & 0.11 \\
\hline
\end{tabular}

A

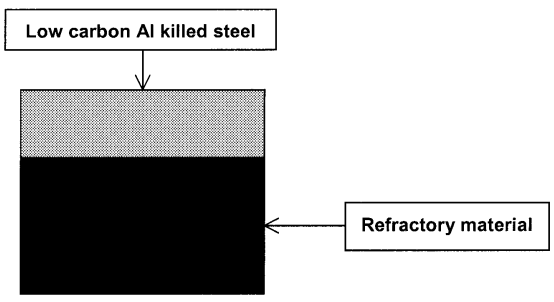

B

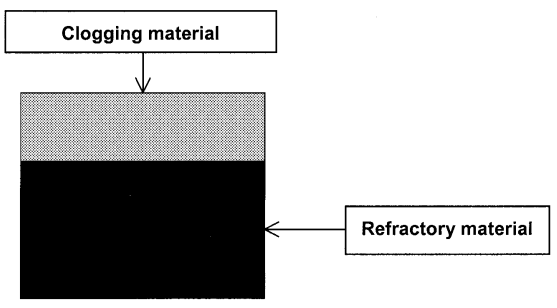

C

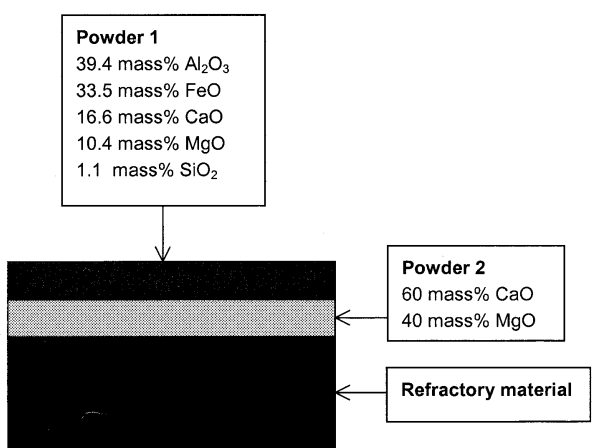

Fig. 1. Overview of the experimental set-up used to simulate the influence of slag elements on the clogging behaviour of refractory materials.

the refractory material, as graphically presented in Fig. 1. The layer consists of two stacked powders of $0.4 \mathrm{~g}$ each. Powder 1 consists of collected clogging material with a small amount of slag components added, $\mathrm{CaO}$ (ALDRICH; Art. 24,856/8) and $\mathrm{MgO}$ (MERCK; Art. 5865), whereas powder 2 simulates an amount of poured slag. It consists of $\mathrm{CaO}$ and $\mathrm{MgO}$ because they proved to be very reactive slag components in preliminary experiments.

The goal of this test is to investigate the chemical stability of potential refractory materials with typical slag phases that may contact the inner wall of the nozzle.

The selected refractory materials are: $\mathrm{Al}_{2} \mathrm{O}_{3}, \mathrm{ZrO}_{2}$, $\mathrm{Al}_{2} \mathrm{O}_{3}-$ carbon, fused $\mathrm{SiO}_{2}$ and $\mathrm{MgO}$ (Table 2). The composition was obtained from the supplier, or determined by XRF (Philips, PW2400) in the case of MgO.

Additionally, a $\mathrm{Al}_{2} \mathrm{O}_{3}-\mathrm{C}$ material that was plasma-coated with pure $\mathrm{Al}_{2} \mathrm{O}_{3}$ was also tested. The coating of approximately $200 \mu \mathrm{m}$ was deposited with a Metco 10-MB system 
using pure $\mathrm{Al}_{2} \mathrm{O}_{3}$ powder (HC-Stark). The coating was also densified at $1600^{\circ} \mathrm{C}$ for $2 \mathrm{~h}$ under an $\mathrm{Ar}$ atmosphere.

After the tests all heated material combinations were embedded in Epofix resin and subsequently ground, for SEM/EDS analysis (Philips XL-30 FEG). Polishing was not performed, as it was found to damage the refractory materials. The samples from the interaction experiments with liquid steel were embedded together with their crucible, as this could not be removed, and cut with a diamond saw, without further grinding or polishing.

To perform TEM-analysis (Philips CM-200 FEG) the samples were embedded in a resin (EPON 812) and ultramicrotomed (LKB ultratome) to a thickness of approximately $70 \mathrm{~nm}$.

Table 2. Composition of the refractory materials used during the experiments.

\begin{tabular}{|l|l|l|l|l|l|}
\hline $\begin{array}{l}\text { Refractory } \\
\text { Material } \\
\begin{array}{l}\text { Composition } \\
{[m a s s \%]}\end{array}\end{array}$ & $\begin{array}{l}\mathrm{Al}_{2} \mathrm{O}_{3^{-}} \\
\text {graphite }\end{array}$ & $\mathrm{Al}_{2} \mathrm{O}_{3}$ & $\begin{array}{l}\text { Fused } \\
\mathrm{SiO}_{2}\end{array}$ & $\mathrm{ZrO}_{2}$ & $\mathrm{MgO}$ \\
\hline $\mathrm{Al}_{2} \mathrm{O}_{3}$ & $62-66$ & $>99.99$ & $0.1-0.3$ & $/$ & $<1$ \\
\hline $\mathrm{C}$ & $19.5-24.5$ & $/$ & $/$ & $/$ & $/$ \\
\hline $\mathrm{SiO}_{2}$ & 3.75 & $/$ & $>99.5$ & $/$ & $<1$ \\
\hline $\mathrm{ZrO}_{2}$ & 4.60 & $/$ & $/$ & 94.8 & $/$ \\
\hline $\mathrm{MgO}$ & 0.37 & $/$ & Traces & $/$ & 96 \\
\hline $\mathrm{BN}$ & $/$ & $/$ & $/$ & $/$ & $/$ \\
\hline $\mathrm{TiO}_{2}$ & 0.99 & $/$ & Traces & $/$ & $/$ \\
\hline $\mathrm{Si}^{\mathrm{Fi}} \mathrm{O}_{3}$ & 1.03 & $/$ & $/$ & $/$ & $/$ \\
\hline $\mathrm{CaO}$ & 0.34 & $/$ & $<0.03$ & $/$ & $<1$ \\
\hline $\mathrm{Y}_{2} \mathrm{O}_{3}$ & $/$ & $/$ & $<0.2$ & $/$ & 2 \\
\hline
\end{tabular}
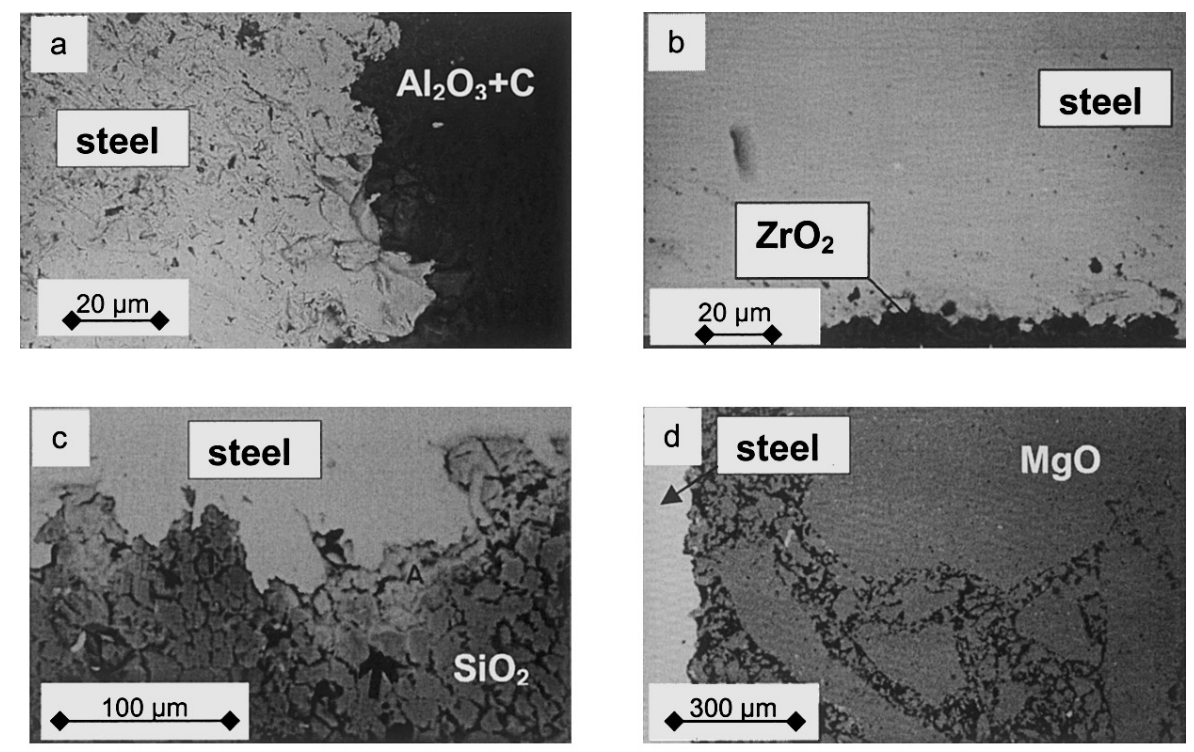

\section{Results and Discussion}

\subsection{Interactions with Liquid Steel} steel took place during the experiments. the steel. uid iron (contact-angle $\left.=122^{\circ}{ }^{17}\right)$.
In all combinations, alumina inclusions are detected in the steel. These particles are also observed during the interaction between liquid steel and Al-free refractory materials, like $\mathrm{ZrO}_{2}$. It seems therefore that $\mathrm{Al}_{2} \mathrm{O}_{3}$ particles are formed in-situ. The dense $\mathrm{Al}_{2} \mathrm{O}_{3}$ crucible was eliminated as a possible source, as observation of the area close to the crucible wall revealed that the crucible was chemically stable. It would seem therefore that some reoxidation of the

No evidence for a chemical interaction zone could be found between the liquid steel and the $\mathrm{Al}_{2} \mathrm{O}_{3}-\mathrm{C}$ refractory material (Fig. 2(a)). No steel infiltration in the refractory material was observed. Alumina particles - in addition to those observed in other combinations - are however found in the steel. The size and morphology of these particles matches well with that of the smaller $(<10 \mu \mathrm{m}) \mathrm{Al}_{2} \mathrm{O}_{3}$ grains of the refractory material. It can therefore be concluded that the carbon in the refractory is partially dissolved and the loosened alumina particles are engulfed by

No interactions were observed between $\mathrm{ZrO}_{2}$ and liquid steel and no pores were induced (Fig. 2(b)). Moreover, there are conditions of non-wetting between $\mathrm{ZrO}_{2}$ and liq-

Between fused silica and liquid steel few interactions took place, although in some places a composition similar

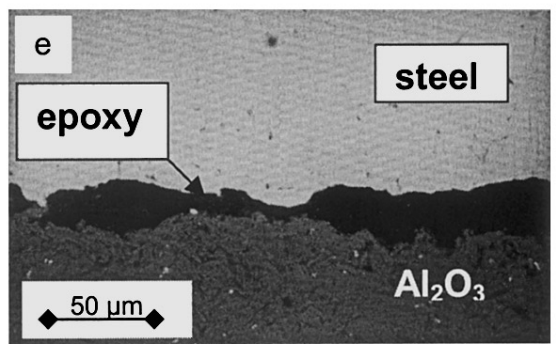

Fig. 2. Electron microscopic images showing the reaction zone of the investigated refractory materials with steel: (a) $\mathrm{Al}_{2} \mathrm{O}_{3}-\mathrm{C}$; (b) $\mathrm{ZrO}_{2}$; (c) $\mathrm{SiO}_{2}$, the arrow indicates a location where fayalite was found; (d) $\mathrm{MgO}$ and (e) $\mathrm{Al}_{2} \mathrm{O}_{3}$. 

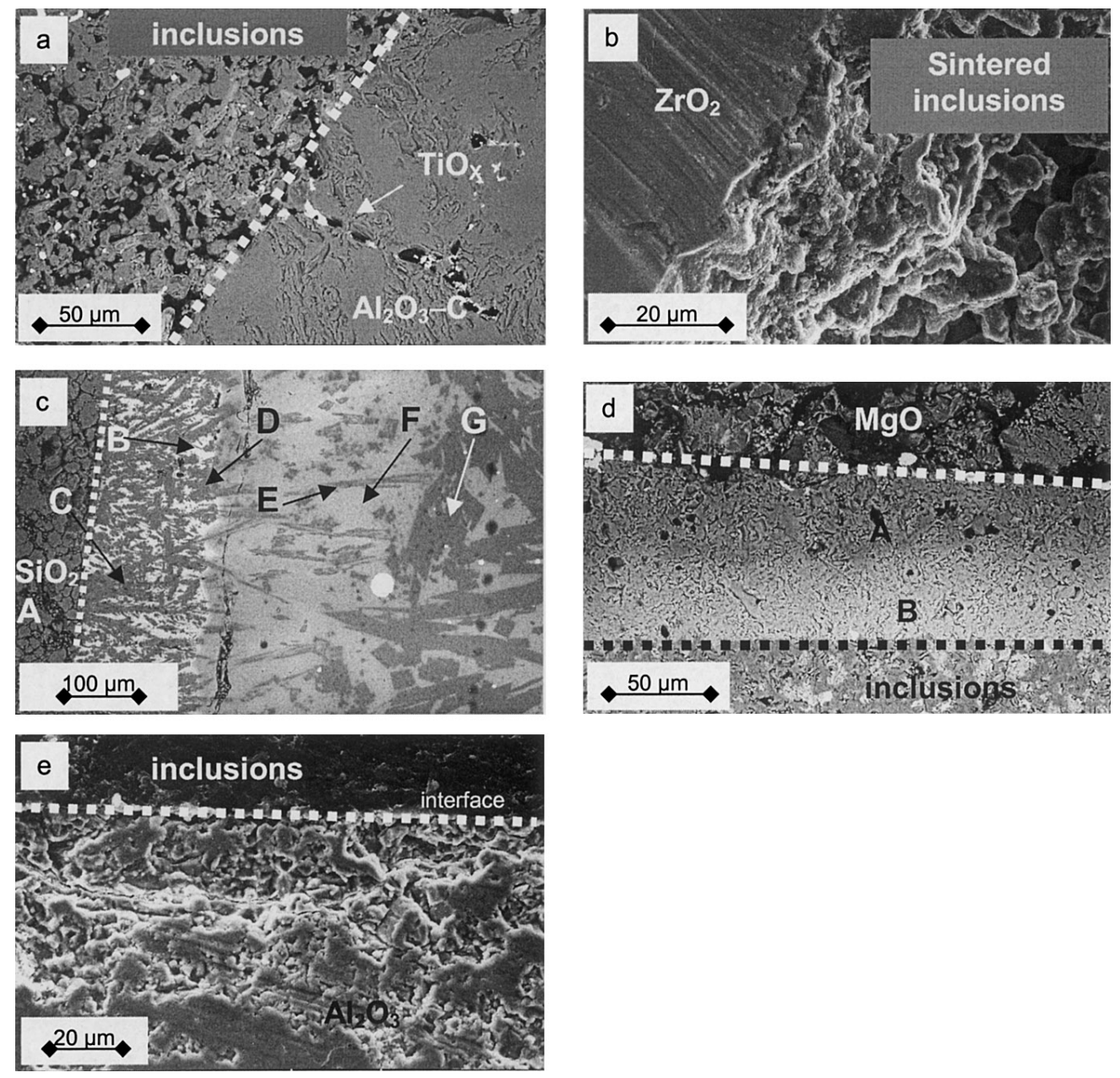

Fig. 3. Electron microscopic images showing the reaction zones of the investigated refractory materials with inclusions: (a) $\mathrm{Al}_{2} \mathrm{O}_{3}-\mathrm{C}$, the dashed line indicates the contact between inclusions and refractory material; (b) $\mathrm{ZrO}_{2}$; (c) $\mathrm{SiO}_{2}$, the dashed line indicates the contact between the refractory material and the reaction phase area (for compositional information see also Table 3); (d) $\mathrm{MgO}$, the dashed lines enclose the reaction zone (for compositional information see Table 4) and (e) $\mathrm{Al}_{2} \mathrm{O}_{3}$.

to that of fayalite was found (Fig. 2(c)). XRD measurements revealed that the fused silica partially crystallised to tetragonal cristobalite. This was confirmed by TEM analysis, although some remanent fused silica was also noticed.

The $\mathrm{MgO}$ refractory disintegrated near the interface but no steel penetration in the $\mathrm{MgO}$ occurred (Fig. 2(d)). However $\mathrm{Al}_{2} \mathrm{O}_{3}, \mathrm{SiO}_{2}$ and $\mathrm{MgO}$ particles from the refractory material were found dispersed in the steel, which is facilitated by the partial disintegration of the $\mathrm{MgO}$ material.

Few or no interactions took place between $\mathrm{Al}_{2} \mathrm{O}_{3}$ and liquid steel and epoxy of the embedding material can be found at the interface as a result of the poor bonding between the two materials. Some evidence of slight erosion of the refractory was observed (Fig. 2(e)). As no new compounds are formed, it was however concluded that $\mathrm{Al}_{2} \mathrm{O}_{3}$ is chemically stable in contact with the liquid steel.

It can be concluded from these experimental observations that all the investigated refractories possess a good to excellent chemical stability in contact with liquid steel.

\subsection{Interactions with Clogged Material}

Inclusions are sintered to the surface of the $\mathrm{Al}_{2} \mathrm{O}_{3}$-carbon refractory. $\mathrm{A} \mathrm{TiO}_{X}$ phase has penetrated along the porosity of the refractory material (Fig. 3(a)). Because this
$\mathrm{TiO}_{X}$ phase is only observed near the reaction zone and because the $\mathrm{TiO}_{X}$ phase contains small amounts of Fe, it is concluded that the $\mathrm{TiO}_{X}$ originates from the inclusions. The sintered inclusions consist mainly of $\mathrm{Al}_{2} \mathrm{O}_{3}$. The brighter areas in the inclusions contain small amounts of $\mathrm{CaO}$ (6.4 mass\%) and $\mathrm{MgO}$ (2.7 mass\%), originating from entrapped slag during pouring, while the sintered dark inclusions are pure $\mathrm{Al}_{2} \mathrm{O}_{3}$. A dispersed fayalite phase $\left(2 \mathrm{FeO} \cdot \mathrm{SiO}_{2}\right)$ is also found in the inclusions. The $\mathrm{Fe}$ originates from the clogged material collected from a used SEN. The oxidation of Fe requires an increased oxygen concentration near the refractory material, which is also detected near the refractory wall of a SEN. This is confirmed by the proposed reaction scheme in the refractory material of an $\mathrm{Al}_{2} \mathrm{O}_{3}$-carbon $\mathrm{SEN}^{3,4,6)}$ :

$$
\begin{gathered}
3 \mathrm{SiO}_{2 \text { (refractory) }}+3 \mathrm{C}_{\text {(refractory) }}=3 \mathrm{SiO}_{(\mathrm{g})}+3 \mathrm{CO}_{(\mathrm{g})} \\
3 \mathrm{SiO}_{(\mathrm{g})}+2 \underline{\mathrm{Al}}_{\mathrm{Fe}}=\mathrm{Al}_{2} \mathrm{O}_{3 \text { (deposit) }}+3 \underline{\mathrm{Si}}_{\mathrm{Fe}} \ldots \ldots . . . . \\
3 \mathrm{CO}_{(\mathrm{g})}+2 \underline{\mathrm{Al}}_{\mathrm{Fe}}=\mathrm{Al}_{2} \mathrm{O}_{3 \text { (deposit) }}+3 \underline{\mathrm{C}}_{\mathrm{Fe}}
\end{gathered}
$$

resulting in the overall reaction:

$$
\begin{aligned}
3 \mathrm{SiO}_{2 \text { (refractory) }} & +3 \mathrm{C}_{\text {(refractory) }}+4 \underline{\mathrm{Al}}_{\mathrm{Fe}} \\
& =2 \mathrm{Al}_{2} \mathrm{O}_{3 \text { (deposit) }}+3 \underline{\mathrm{Si}}_{\mathrm{Fe}}+3 \underline{\mathrm{C}}_{\mathrm{Fe}}
\end{aligned}
$$


A small amount of inclusions is attached to the $\mathrm{ZrO}_{2}$ refractory (Fig. 3(b)), which results in a sintered layer of approximately $100 \mu \mathrm{m}$. No enrichment of the $\mathrm{ZrO}_{2}$ by $\mathrm{Al}$ or $\mathrm{Fe}$, neither of the $\mathrm{Al}_{2} \mathrm{O}_{3}$ by $\mathrm{Zr}$ could be observed. Although some limited interaction between the $\mathrm{ZrO}_{2}$ and the clogged material was observed, it is very unlikely to be of a chemical nature.

Fused silica partially transforms in cristobalite ${ }^{10)}$ and a reaction zone of approximately $150 \mu \mathrm{m}$ forms, as shown in Fig. 3(c). Cracks are formed due to the difference in thermal expansion coefficient. In order to locate the initial contact plane between the $\mathrm{SiO}_{2}$ refractory and the inclusions, a similar experiment was carried out using a $\mathrm{ZrO}_{2}$ powder marker. The position of the inert marker after the experiment is indicated on Fig. 3(c).

On the cristobalite side of the interaction couple (phase A in Fig. 3(c) and Table 3), a white iron cordierite phase (phase $\mathrm{B}$ ) is found in combination with phases containing mainly $\mathrm{Al}_{2} \mathrm{O}_{3}$ and $\mathrm{SiO}_{2}$ (phases $\mathrm{C}$ and $\mathrm{D}$ ). As the composition of phases $\mathrm{C}$ and $\mathrm{D}$ varies over a wide range and is outside that of the crystalline mullite solid solubility region in the binary $\mathrm{Al}_{2} \mathrm{O}_{3}-\mathrm{SiO}_{2}$ system, we assume these phases to be glasses. The glassy phase (phase $\mathrm{C}$ ) close to the pristine cristobalite contains remarkably lower amounts of $\mathrm{Al}_{2} \mathrm{O}_{3}$ in comparison with phase $\mathrm{D}$, which is closer to the initial interface. The phases $\mathrm{C}$ and $\mathrm{D}$ can be correlated to the constituent glass phases of the metastable immiscibility region reported in the $\mathrm{SiO}_{2}-\mathrm{Al}_{2} \mathrm{O}_{3}$ phase diagram. ${ }^{18)}$

On the inclusions side of the interaction couple, three phases can be differentiated; phase E, with the same composition as phase $\mathrm{D}$, phase $\mathrm{F}$ which contains considerable amounts of $\mathrm{FeO}_{X}$ in addition to $\mathrm{SiO}_{2}$ and $\mathrm{Al}_{2} \mathrm{O}_{3}$ and phase $\mathrm{G}$, being large crystalline mullite crystals. The $\mathrm{SiO}_{2}-$ $\mathrm{Al}_{2} \mathrm{O}_{3}-\mathrm{FeO}_{X}$ phase (phase $\mathrm{F}$ ) is actually a cristobalite solid solution that is formed directly from the melt during cooling.

Although the reaction zone is complex, a first attempt to understand the phase sequence has been made. During the heating process, a liquid with approximately the composition of the iron cordierite phase was formed at the initial contact plane from the inclusions and the refractory. At $1550^{\circ} \mathrm{C}$, this liquid penetrated the silica refractory along the grain boundaries, providing a fast diffusion path for $\mathrm{Si}$ and Al. The inward diffusion of $\mathrm{Al}$ from the dissolved inclusions resulted in the formation of the $\mathrm{Al}_{2} \mathrm{O}_{3}-\mathrm{SiO}_{2}$ glass phases $\mathrm{C}$ and $\mathrm{D}$. This glass phase is even extended as phase $\mathrm{E}$ in the melt on the inclusion side, as can be deduced from the growth direction. At the reaction front in the refractory, $\mathrm{SiO}_{2}$ dissolves in the liquid iron cordierite and diffuses to the inclusion side resulting in the formation of a $\mathrm{SiO}_{2}$-rich melt (phase F) and the crystallisation of mullite (phase $\mathrm{G}$ ).

Chemical interactions between the $\mathrm{MgO}$ refractory material and the inclusions resulted in a reaction layer with a thickness of approximately $100 \mu \mathrm{m}$ (Fig. 3(d)). In the reaction layer $\mathrm{Al}_{2} \mathrm{O}_{3}, \mathrm{MgO}$ and $\mathrm{FeO}$ are observed in two distinct sublayers. The layer close to the refractory contains 19 mass $\% \mathrm{MgO}, 73$ mass $\% \quad \mathrm{Al}_{2} \mathrm{O}_{3}$ and 8 mass $\% \mathrm{FeO}$, whereas the other layer is composed of 8 mass $\% \mathrm{MgO}$, 64 mass $\% \mathrm{Al}_{2} \mathrm{O}_{3}$ and 28 mass $\% \mathrm{FeO}$. The amount of $\mathrm{MgO}$ and $\mathrm{Al}_{2} \mathrm{O}_{3}$ increases towards the refractory material side, whereas the $\mathrm{FeO}$ content decreases. The surface of the
Table 3. Chemical composition (mass $\%$ ) of the phases found in the interaction zone between $\mathrm{SiO}_{2}$ and inclusions (see also Fig. 2(c)).

\begin{tabular}{|l|l|l|l|l|}
\hline Phase & $\begin{array}{l}\mathrm{Al}_{2} \mathrm{O}_{3} \\
{[\text { mass\%] }}\end{array}$ & $\begin{array}{l}\mathrm{SiO}_{2} \\
{[\text { mass\% } \%]}\end{array}$ & $\begin{array}{l}\mathrm{FeO} \\
{[\mathrm{mass} \%]}\end{array}$ & $\begin{array}{l}\text { Corresponding } \\
\text { Phase }\end{array}$ \\
\hline $\mathrm{A}$ & 0 & 100 & 0 & Cristobalite \\
\hline $\mathrm{B}$ & $18.0 \pm 0.4$ & $42.0 \pm 1.3$ & $40.0 \pm 1.6$ & Iron Cordierite \\
\hline $\mathrm{C}$ & $41 \pm 13$ & $58 \pm 13$ & $1 \pm 1$ & $\mathrm{SiO}_{2}-\mathrm{Al}_{2} \mathrm{O}_{3}$ glass phase \\
\hline $\mathrm{D}$ & $56 \pm 19$ & $43 \pm 17$ & $1 \pm 1$ & $\mathrm{SiO}_{2}-\mathrm{Al}_{2} \mathrm{O}_{3}$ glass phase \\
\hline $\mathrm{E}$ & $58 \pm 17$ & $41 \pm 15$ & $1 \pm 1$ & $\mathrm{SiO}_{2}-\mathrm{Al}_{2} \mathrm{O}_{3}$ glass phase \\
\hline $\mathrm{F}$ & $19 \pm 1$ & $62 \pm 3$ & $19 \pm 2$ & Cristobalite solid solution \\
\hline $\mathrm{G}$ & $72 \pm 1$ & $28 \pm 1$ & 0 & Mullite \\
\hline
\end{tabular}

$\mathrm{MgO}$ refractory next to the reaction layer partially disintegrated and an Fe-rich phase penetrated the refractory material up to a depth of 300 to $500 \mu \mathrm{m}$.

No sign of interactions was detected between the $\mathrm{Al}_{2} \mathrm{O}_{3}$ in the refractory and the inclusions (Fig. 3(e)). This observation indicates that pure and dense $\mathrm{Al}_{2} \mathrm{O}_{3}$ does not interact with $\mathrm{Al}_{2} \mathrm{O}_{3}$ inclusions and steel at laboratory conditions.

These laboratory simulations proved that pure $\mathrm{Al}_{2} \mathrm{O}_{3}$ exhibits no noticeable interaction with retrieved clogging material at $1550^{\circ} \mathrm{C}$, whereas in the case of $\mathrm{ZrO}_{2}$, inclusions were found to adhere to the refractory material. The $\mathrm{SiO}_{2}$ and $\mathrm{MgO}$ refractory are not chemically stable in contact with the retrieved clogging material at $1550^{\circ} \mathrm{C}$.

\subsection{Interactions with Synthetic Slag}

At some locations in the $\mathrm{Al}_{2} \mathrm{O}_{3}$-carbon refractory material, $\mathrm{CaO}$ originating from the synthetic slag penetrated up to a depth of approximately $400 \mu \mathrm{m}$ (Fig. 4(a)). Near the interface $\mathrm{Al}_{2} \mathrm{O}_{3} \cdot \mathrm{CaO}$ is formed. Moving further away from the interface into the refractory material, the $\mathrm{CaO}$ concentration decreases from $30.1 \pm 1.9$ mass $\%$ at $200 \mu \mathrm{m}$ to $14.7 \pm 1.5$ mass $\%$ at $400 \mu \mathrm{m}$.

The synthetic slag penetrated the $\mathrm{ZrO}_{2}$ refractory, resulting in a reaction layer of approximately $200 \mu \mathrm{m}$ (Fig. 4(b)). The reaction layer consists mainly of $\mathrm{Al}_{2} \mathrm{O}_{3} \cdot \mathrm{MgO}$ and two $\mathrm{ZrO}_{2}$-phases with a different $\mathrm{CaO}$ content. At the interface with the synthetic slag, the $\mathrm{Y}_{2} \mathrm{O}_{3}$-stabilised $\mathrm{ZrO}_{2}$ (tetragonal) is converted into $\mathrm{CaO} \cdot \mathrm{ZrO}_{2} \cdot{ }^{19)}$ Further away from the interface, a large grained $\mathrm{ZrO}_{2}$ phase is formed with approximately 10 mass $\% \mathrm{CaO}$ and 3 mass $\% \mathrm{Y}_{2} \mathrm{O}_{3}$. The formation of large grains, approximately $10 \mu \mathrm{m}$, is typical for cubic zirconia, which in this case is stabilised by a mixture of $\mathrm{CaO}$ and $\mathrm{Y}_{2} \mathrm{O}_{3}$, whereas tetragonal yttria-stabilised zirconia has a grain size well below $1 \mu \mathrm{m}$.

The slag also penetrated the cristobalite refractory, resulting in a reaction layer of approximately $100 \mu \mathrm{m}$, as shown in Fig. 4(c). In the reaction layer, 2 phases could be identified: a dendritic silica phase and a slag phase composed of $62.1 \pm 2.7$ mass $\% \mathrm{SiO}_{2} ; 11.6 \pm 0.1$ mass $\% \mathrm{MgO}$; $11.8 \pm 0.5$ mass $\% \quad \mathrm{Al}_{2} \mathrm{O}_{3}$ and $14.5 \pm 0.6$ mass $\% \mathrm{CaO}$. This slag phase has a liquidus temperature of $1540 \mathrm{~K} .{ }^{20)}$

The $\mathrm{MgO}$ refractory surface disintegrated at the initial reaction front and the refractory is penetrated along the grain boundaries by the synthetic slag leading to the formation of monticellite (Fig. 4(d)). Penetration depths of approximately $2 \mathrm{~mm}$ were observed.

The $\mathrm{Al}_{2} \mathrm{O}_{3}$ refractory reacted with the synthetic slag resulting in a reaction zone of approximately $100 \mu \mathrm{m}$ thick, as shown in Fig. 4(e). The reaction zone consists of four different phases, summarised in Table 4. The phase (A) 

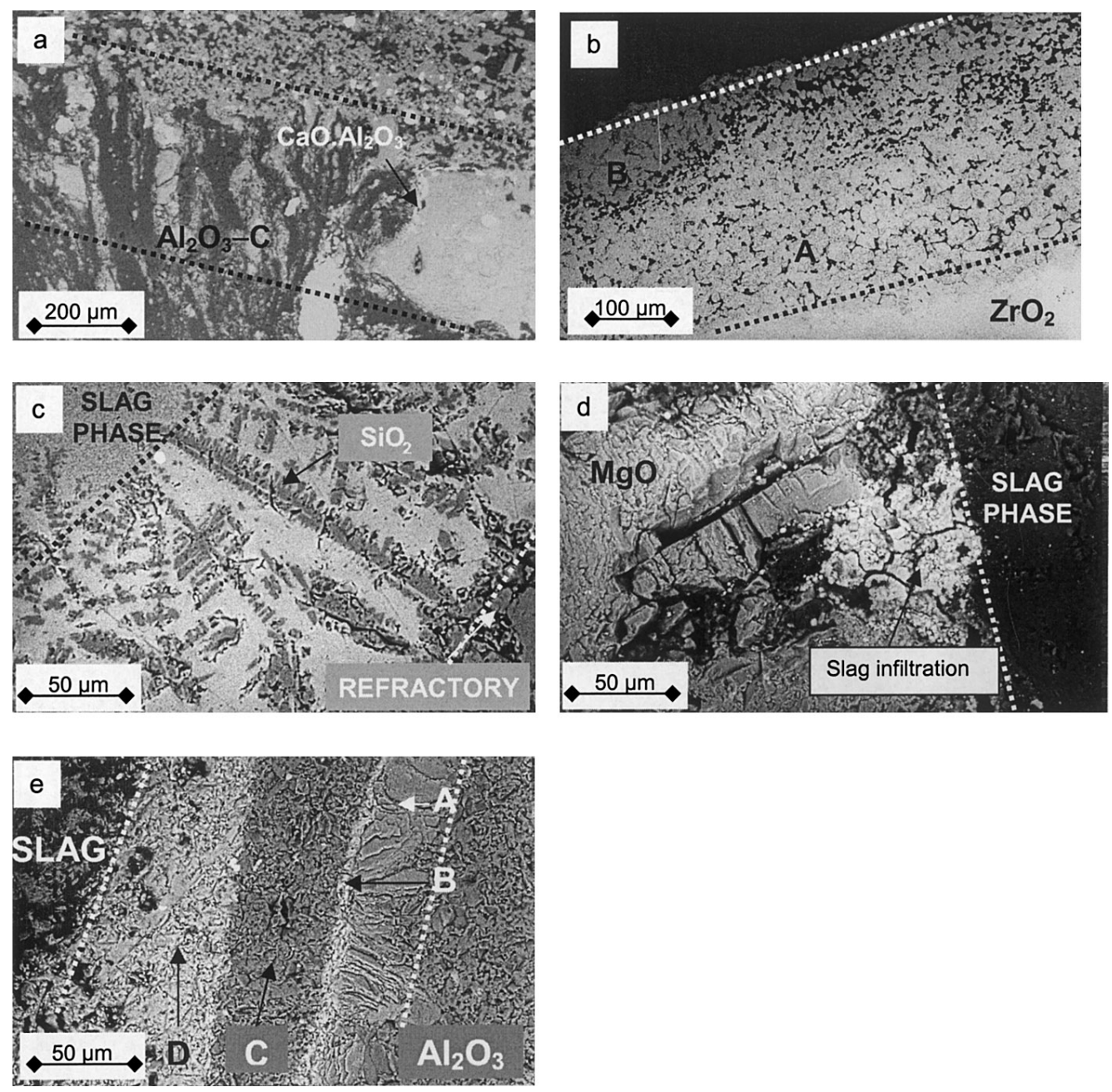

Fig. 4. Electron microscopic images of the reaction zones of the investigated refractory materials with the synthetic slag: (a) $\mathrm{Al}_{2} \mathrm{O}_{3}-\mathrm{C}$, the dashed lines indicate the slag permeation zone; (b) $\mathrm{ZrO}_{2}$, the dashed lines indicate the reaction zone (for compositional information see Table 5); (c) $\mathrm{SiO}_{2}$ the dashed lines indicate the reaction zone; (d) $\mathrm{MgO}$, the dashed line indicates the interface and (e) $\mathrm{Al}_{2} \mathrm{O}_{3}$, the dashed lines indicate the reaction zone (for compositional information see Table 6).

Table 4. Chemical composition (mass\%) of the phases found in the interaction zone between $\mathrm{MgO}$ and inclusions (see also Fig. 2(d)).

\begin{tabular}{|l|l|l|l|}
\hline Phase & $\begin{array}{l}\mathrm{MgO} \\
\left(\text { mass\%) }^{2}\right.\end{array}$ & $\begin{array}{l}\mathrm{Al}_{2} \mathrm{O}_{3} \\
(\text { mass\% })\end{array}$ & $\begin{array}{l}\mathrm{FeO} \\
(\text { mass\%) }\end{array}$ \\
\hline $\mathrm{A}$ & $19.0 \pm 2.4$ & $73.0 \pm 2.5$ & $8.0 \pm 4.7$ \\
\hline $\mathrm{B}$ & $8.2 \pm 1.0$ & $64.4 \pm 3.6$ & $27.5 \pm 3.2$ \\
\hline
\end{tabular}

Table 5. Chemical composition (mass\%) of the phases found in the interaction zone between $\mathrm{ZrO}_{2}$ and synthetic slag (see also Fig. 3(b)).

\begin{tabular}{|l|l|l|l|}
\hline & $\begin{array}{l}\mathrm{ZrO} \\
(\text { mass\%) }\end{array}$ & $\begin{array}{l}\mathrm{CaO} \\
(\text { mass\%) }\end{array}$ & $\begin{array}{l}\mathrm{Y}_{2} \mathrm{O}_{3} \\
(\text { mass\%) }\end{array}$ \\
\hline Phase A & $87.9 \pm 3.3$ & $9.3 \pm 1.2$ & $2.8 \pm 2.8$ \\
\hline Phase B & $67.8 \pm 2.5$ & $27.1 \pm 1.4$ & $5.1 \pm 1.9$ \\
\hline
\end{tabular}

Table 6. Chemical composition (mass\%) of the phases identified in the interaction layer between synthetic slag and pure $\mathrm{Al}_{2} \mathrm{O}_{3}$ (Fig. 3(e)).

\begin{tabular}{|l|l|l|l|l|}
\hline Phase & $\begin{array}{l}\mathrm{Al}_{2} \mathrm{O}_{3} \\
{[\text { mass\%] }}\end{array}$ & $\begin{array}{l}\mathrm{CaO} \\
{[\text { mass\%] }}\end{array}$ & $\begin{array}{l}\mathrm{MgO} \\
{[\text { mass\% }}\end{array}$ & $\begin{array}{l}\text { Corresponding } \\
\text { Phase }\end{array}$ \\
\hline $\mathrm{A}$ & $92.1 \pm 0.7$ & $7.9 \pm 0.7$ & 0 & $6 \mathrm{Al}_{2} \mathrm{O}_{3} \cdot \mathrm{CaO}$ \\
\hline $\mathrm{B}$ & $79.1 \pm 0.4$ & $20.9 \pm 0.4$ & 0 & $2 \mathrm{Al}_{2} \mathrm{O}_{3} \cdot \mathrm{CaO}$ \\
\hline $\mathrm{C}$ & $74.8 \pm 2.0$ & 0 & $25.2 \pm 1.6$ & $\mathrm{Al}_{2} \mathrm{O}_{3} . . \mathrm{MgO}$ \\
\hline $\mathrm{D}$ & $81.0 \pm 1.3$ & $19.0 \pm 0.5$ & 0 & $2 \mathrm{Al}_{2} \mathrm{O}_{3} \cdot \mathrm{CaO}$ \\
\hline
\end{tabular}

found next to the refractory material consists of $\mathrm{Al}_{2} \mathrm{O}_{3}$ and small amounts of $\mathrm{CaO}$, resembling the $6 \mathrm{Al}_{2} \mathrm{O}_{3} \cdot \mathrm{CaO}$ phase. Subsequently, a very thin layer of $2 \mathrm{Al}_{2} \mathrm{O}_{3} \cdot \mathrm{CaO}$, phase $\mathrm{B}$, can be observed. Moving further towards the slag, $\mathrm{Al}_{2} \mathrm{O}_{3} \cdot \mathrm{MgO}$ (spinel, phase $\mathrm{C}$ ) is detected and finally, $2 \mathrm{Al}_{2} \mathrm{O}_{3} \cdot \mathrm{CaO}$ (region D) is detected close to the synthetic slag. The synthetic slag itself consists of three different phases: $2 \mathrm{Al}_{2} \mathrm{O}_{3} \cdot \mathrm{CaO}, \mathrm{Al}_{2} \mathrm{O}_{3} \cdot \mathrm{MgO}$ and Fe-droplets.

Since new compounds can be formed between the slag components $\mathrm{CaO}, \mathrm{MgO}$ and the refractory materials it is concluded that contact between them has a negative influence for all of the investigated materials.

\section{4. $\mathrm{Al}_{2} \mathrm{O}_{3}$ Plasma Coated $\mathrm{Al}_{2} \mathrm{O}_{3}-\mathrm{C}$}

The previous results show that $\mathrm{Al}_{2} \mathrm{O}_{3}$ is the most resistent in contact with liquid steel and clogged material. $\mathrm{Al}_{2} \mathrm{O}_{3}-\mathrm{C}$ is chemically much less inert, but has good mechanical properties and is thermal shock resistant. Therefore it would seem that a $\mathrm{Al}_{2} \mathrm{O}_{3}$ coated $\mathrm{Al}_{2} \mathrm{O}_{3}-\mathrm{C}$ refractory materials could present a good solution. The material was tested in contact with liquid steel, clogging material and synthetic slag.

The sample with the as-deposited coating sintered with 


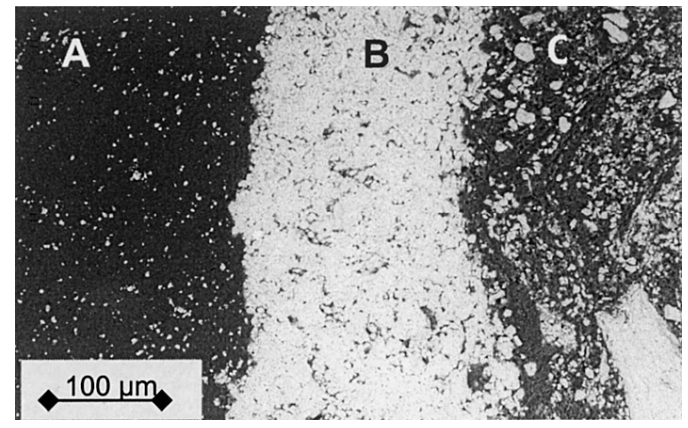

Fig. 5. Electron microscopic image of the interaction between inclusions (A) and a densified $\mathrm{Al}_{2} \mathrm{O}_{3}$ (B) plasma coated $\mathrm{Al}_{2} \mathrm{O}_{3}-\mathrm{C}(\mathrm{C})$ sample.

the clogging material. From this it was concluded that the reactions (1)-(4) that occur with the $\mathrm{Al}_{2} \mathrm{O}_{3}-\mathrm{C}$ material were not sufficiently blocked by the coating. Therefore the coating materials was densified at high temperature. After this treatment no interaction with inclusions was found (Fig. 5). The densified material also withstood the contact with liquid steel well. Some liquid steel did however penetrate the coating in a few locations in the form of small steel droplets with a size of approximately $2 \mu \mathrm{m}$. The reaction with synthetic slag is very similar as was described for the bulk $\mathrm{Al}_{2} \mathrm{O}_{3}$.

\section{Conclusions}

Some $\mathrm{Al}_{2} \mathrm{O}_{3}$ grains are dispersed in the liquid steel due to carbon dissolution when $\mathrm{Al}_{2} \mathrm{O}_{3}$-carbon contacts steel. Intense sintering occurred between this refractory material and inclusions, while calcium-aluminates are formed in contact with the slag phase. $\mathrm{ZrO}_{2}$ does not react with liquid steel, but sintering occurred between inclusions and the refractory material. $\mathrm{Ca}$ enrichment of $\mathrm{ZrO}_{2}$ takes place in contact with slag, forming a $\mathrm{CaO}-\mathrm{Y}_{2} \mathrm{O}_{3}$-stabilised zirconia or even $\mathrm{CaO} \cdot \mathrm{ZrO}_{2}$. After partial transformation of fused silica into cristobalite, due to the elevated temperatures, cracks appeared. Nevertheless, no interaction takes place with liquid steel. Silica however reacted intensively in contact with inclusions and synthetic slag. Although $\mathrm{MgO}$ disintegrates near the reaction interface, no steel penetration occurred. Nevertheless, the synthetic slag penetrated the refractory material and inclusions are sintered on the $\mathrm{MgO}$ refractory. $\mathrm{Al}_{2} \mathrm{O}_{3}$ does not react with liquid steel nor with inclusions. In contact with a synthetic slag calcium-aluminates are formed. It is concluded that pure $\mathrm{Al}_{2} \mathrm{O}_{3}$ possesses interesting chemical properties as an anti-clogging material and with some tests using a $\mathrm{Al}_{2} \mathrm{O}_{3}$ coated $\mathrm{Al}_{2} \mathrm{O}_{3}-\mathrm{C}$ material a possible solution to the clogging problem was indicated.

\section{Acknowledgements}

The authors would like to thank Dr. H. Kumar for his thermodynamical remarks and Ing. S. Goovaerts for the XRF-analysis.

\section{REFERENCES}

1) T. Smith: Steel Times Int., 226 (1998), 389.

2) A. F. Dick, X. Yu, R. J. Pomfret and K. S. Coley: ISIJ Int., 37 (1997), 102.

3) F. Hauck and J. Potschke: Arch. Eisenhüttenwes., 53 (1982), 133.

4) J. Poirier, M. A. Guiban, P. Tassot, E. Hanse, B. Thillo and, P. Benson: Proc. Global Development of Refractories, The Technical Association of Refractories, Tokyo, (1995), 79.

5) Y. Fukuda, Y. Ueshima and S. Mizoguchi: ISIJ Int., 32 (1992), 164.

6) K. Sasai and Y. Mizukami: ISIJ Int., 34 (1994), 802.

7) F. G. Wilson, M. J. Heesom, A. Nicholson and A. W. Hills: Ironmaking Steelmaking, 14 (1987), 296.

8) K. G. Rackers and B. G. Thomas: 78th Steelmaking Conf. Proc., ISS, Warrendale, PA, (1995), 723.

9) K. Harold, A. Elksnitis and K. Oguri: Proc. Int. Symp. on Advances in Refractories for the Metallurgical Industries III, ed. by C. Allaire and M. Rigaud, CIM Met, Soc., Québec, (1999), 163.

10) Y. Vermeulen, B. Blanpain, P. Wollants, F. Haers, L. Peeters and C. Vercruyssen: Proc. 3rd European Conf. on Continuous Casting, The Spanish Committee of Technology of the Unión de Emprésas Siderúrgicas-UNESID, Madrid, (1998), 1013.

11) S. N. Singh: Metall. Trans., 5 (1974), 2165

12) G. C. Duderstadt, R. K. Iyengar and J. M. Matesa: J. Met., 20 (1968), 89

13) W. Brandl and A. Sormann: Proc. 3rd European Conf. on Continuous Casting, The Spanish Committee of Technology of the Unión de Emprésas Siderúrgicas-UNESID, Madrid, (1998), 714.

14) J. Kärjä, H. Nevala, U. Hintzen and M. Wiesel: Stahl Eisen, 113 (1993), 73.

15) N. Bannenberg: 78th Steelmaking Conf. Proc., ISS, Warrendale, PA, (1995), 457.

16) B. Sundman, B. Jansson and J. O. Andersson: Calphad, 9 (1985), 153.

17) A. W. Cramb and I. Jimbo: ISS Transactions, 11 (1990), 67.

18) S. H. Risbud and J. A. Pask: J. Mater. Sci., 13 (1978), 2449.

19) H. M., Ondik and H. F. McMurdie: Phase Diagrams for Zirconium and Zirconia Systems, 1st Ed., The Amer. Ceram. Soc., Westerville, OH, (1998), 45.

20) FactSage software, http://www.factsage.com, accessed to February 6. 